\title{
Slaughterhouse wastewater treatment by combined anaerobic baffled reactor and anaerobic filter: study of OLR and HRT optimization in $\mathrm{ABR} / \mathrm{AF}$ reactors
}

\author{
Zabihollah Yousefi ${ }^{1 *}$, Mohammad Behbodi ${ }^{1}$, Reza Ali Mohammadpour ${ }^{2}$ \\ ${ }^{1}$ Department of Environmental Health Engineering, School of Public Health, Mazandaran University of Medical Sciences, Sari, Iran \\ ${ }^{2}$ Department of Biostatistics, School of Public Health, Mazandaran University of Medical Sciences, Sari, Iran
}

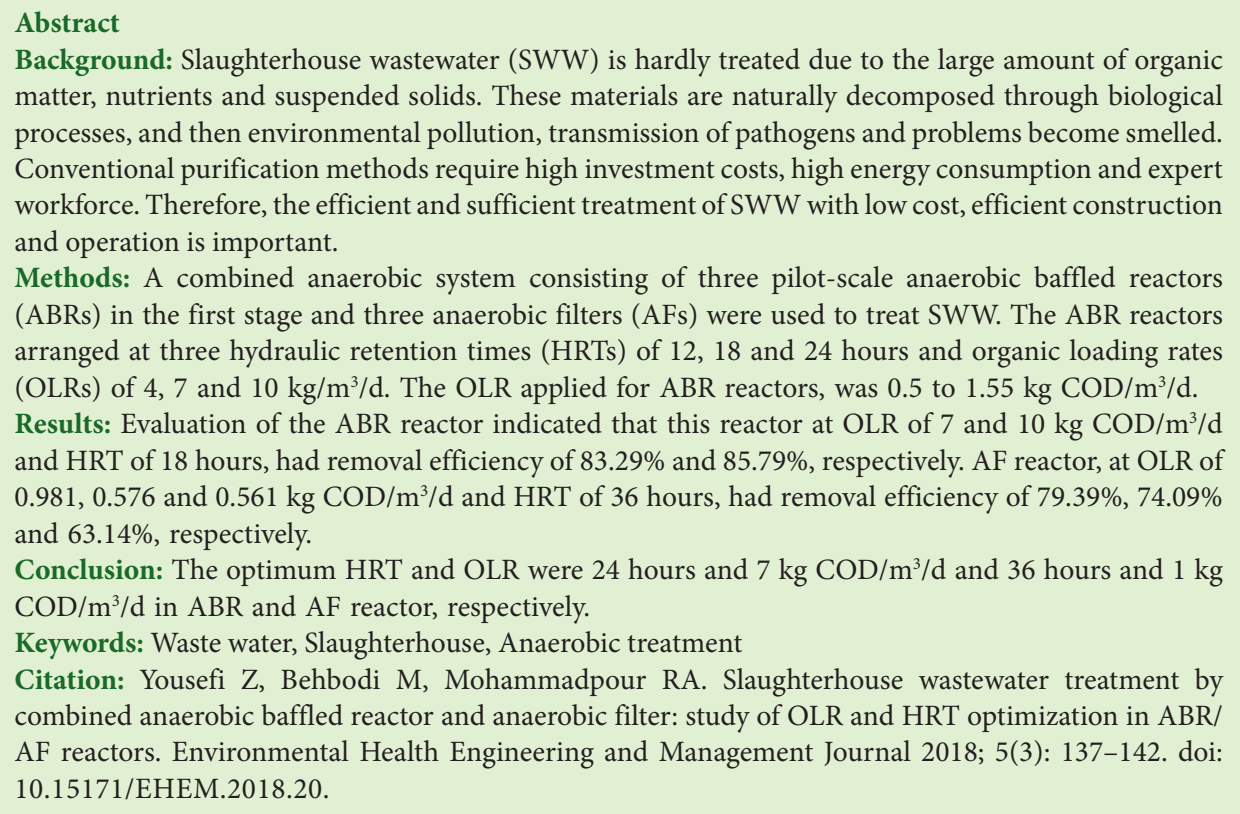
matter, nutrients and suspended solids. These materials are naturally decomposed through biological processes, and then environmental pollution, transmission of pathogens and problems become smelled. Conventional purification methods require high investment costs, high energy consumption and expert workforce. Therefore, the efficient and sufficient treatment of SWW with low cost, efficient construction and operation is important.

Methods: A combined anaerobic system consisting of three pilot-scale anaerobic baffled reactors (ABRs) in the first stage and three anaerobic filters (AFs) were used to treat SWW. The ABR reactors arranged at three hydraulic retention times (HRTs) of 12, 18 and 24 hours and organic loading rates (OLRs) of 4,7 and $10 \mathrm{~kg} / \mathrm{m}^{3} / \mathrm{d}$. The OLR applied for ABR reactors, was 0.5 to $1.55 \mathrm{~kg} \mathrm{COD} / \mathrm{m}^{3} / \mathrm{d}$. Results: Evaluation of the ABR reactor indicated that this reactor at OLR of 7 and $10 \mathrm{~kg} \mathrm{COD} / \mathrm{m}^{3} / \mathrm{d}$ and HRT of 18 hours, had removal efficiency of $83.29 \%$ and $85.79 \%$, respectively. AF reactor, at OLR of $0.981,0.576$ and $0.561 \mathrm{~kg} \mathrm{COD} / \mathrm{m}^{3} / \mathrm{d}$ and HRT of 36 hours, had removal efficiency of $79.39 \%, 74.09 \%$ and $63.14 \%$, respectively.

Conclusion: The optimum HRT and OLR were 24 hours and $7 \mathrm{~kg} \mathrm{COD} / \mathrm{m}^{3} / \mathrm{d}$ and 36 hours and $1 \mathrm{~kg}$ $\mathrm{COD} / \mathrm{m}^{3} / \mathrm{d}$ in $\mathrm{ABR}$ and $\mathrm{AF}$ reactor, respectively.

Keywords: Waste water, Slaughterhouse, Anaerobic treatment

Citation: Yousefi Z, Behbodi M, Mohammadpour RA. Slaughterhouse wastewater treatment by combined anaerobic baffled reactor and anaerobic filter: study of OLR and HRT optimization in ABR/ AF reactors. Environmental Health Engineering and Management Journal 2018; 5(3): 137-142. doi: 10.15171/EHEM.2018.20.

Article History: Received: 22 April 2018 Accepted: 11 August 2018 ePublished: 20 September 2018

\section{Introduction}

The slaughter industry demands large amounts of water for its processes include killing, hide or hair removal, carcass washing and cleanup operations and generates substantial volumes of wastewater (1). Slaughterhouse wastewater (SWW) contains high levels of organics (blood, fecal matter, urine, paunch and undigested food), pathogenic and non-pathogenic viruses, bacteria, nitrogen and phosphorus from organic materials $(2,3)$. Several studies have described the common characteristics of SWW and reported that raw wastewater have biochemical oxygen demand $(\mathrm{BOD}=834$ to $16680 \mathrm{mg} / \mathrm{L})$, chemical oxygen demand $(\mathrm{COD}=1790$ to $27800 \mathrm{mg} / \mathrm{L})$, total phosphorus $(\mathrm{TP}=34$ to 720$)$, total nitrogen $(\mathrm{TN}=106$ to $550 \mathrm{mg} / \mathrm{L})$, total kjeldahl nitrogen $(\mathrm{TKN}=90$ to $525 \mathrm{mg} / \mathrm{L}), \mathrm{pH} 6.7$ to 8 and electrical conductivity 1.99 to $9.14 \mathrm{mS}$ (4-11).
SWW as a source of environmental, water and food contamination causes serious environmental problems by direct discharge into water body (deoxygenation of rivers and contamination of groundwater). So, this wastewater must be treated before final discharge (12). Similar to municipal wastewater plant, SWW treatment methods fall into three main categories include primary, secondary, and tertiary treatment by various methods such as physical (flow equalization, dissolved air flotation), chemical (coagulation-flocculation) and biological (aerobic, anaerobic) systems $(1,13,14)$. Biological treatment is usually the most cost-effective technology for SWW. Among several biological methods, the anaerobic process is an attractive alternative for slaughterhouse wastewater treatment (SWWT) plants due to low construction and operation cost, high organic loading rate (OLR), low 
sludge production, simple design, high solids retention time, high stability to organic shocks and potential to produce biogas. In anaerobic systems, microorganisms break down biodegradable materials in the absence of oxygen and produce methane, carbon dioxide and hydrogen. Depending on the mechanism used to achieve biomass detention, these reactors can be classified into three major groups include the fixed film, suspended growth and hybrid reactors $(1,13,14)$. Despite these advantages, some drawbacks of anaerobic treatment such as long retention time and instability due to hydraulic and organic shock loads lead to the development of the high-rate reactors that separate hydraulic retention time (HRT) from solid retention time (SRT). Such separation which allows the slow-growing bacteria to remain within the reactor independent of the wastewater flow and allows a higher volumetric load rate, significantly increased reactor removal efficiencies $(11,15)$. Typical high rate anaerobic reactor used for SWW include upflow anaerobic sludge blanket (UASB), anaerobic baffled reactor $(A B R)$, anaerobic filter $(A F)$, anaerobic sequencing batch reactor (SBR), anaerobic attached film expanded bed reactor (AAFEB) and anaerobic rotating biological contactor $(\mathrm{RBC})(1,13,14)$. Anaerobic treatment alone is not sufficient to achieve a high degree of treatment and acceptable discharge standard in terms of BOD, COD and nutrients $(\mathrm{N}, \mathrm{P})$. One of the technological solutions being considered is an ABR combined with AF (AF). ABR is one of these high-rate anaerobic systems developed by McCarty and co-workers at Stanford University. The ABR has been described as a series of UASBs, in which hanging and standing baffles divide the reactor into different compartments and flow zones $(16,17)$. In each compartment, high concentrations of biomass that tend to settle and rise with horizontal flow stream and gas production, cause the reactor work at a relatively high SRT and low HRT and provide higher treatment rate, higher resilience to organic and hydraulic shock loads, longer biomass retention times and lower sludge yields than other anaerobic treatment systems $(17,18)$. Moreover, the reactor ability to separate acidogenesis and methanogenesis phase and develop different bacterial groups under more favorable conditions allowing the reactor to behave as a two-phase system and enhancing reactor stability without the associated control problems and high costs $(19,20)$. Boopathy and Tilche successfully treated high-strength molasses wastewater using a hybrid ABR. At OLR of $20 \mathrm{~kg} \mathrm{COD} / \mathrm{m}^{3} / \mathrm{d}$, soluble COD removal efficiencies over 70\% were achieved (18). Gopala Krishna et al reported COD and BOD removal efficiencies more than $90 \%$ at 8 and 10 hours HRT and OLRs of 1.5 to 1.2 $\mathrm{kg} \mathrm{COD} / \mathrm{m}^{3} / \mathrm{d}(21)$. Bodkhe reported removal efficiencies of $84 \%$ for COD and $87 \%$ for ABR in treating domestic wastewater at an HRT of 6 hours (22). Cao and Mehrvar used the combined $\mathrm{ABR}$ and $\mathrm{UV} / \mathrm{H}_{2} \mathrm{O}_{2}$ processes to treat a synthetic SWW, and reported treatment efficiencies of
$89.9 \%$ for TOC, $97.7 \%$ for COD and $96.6 \%$ for $\mathrm{BOD}_{5}$. They also found that combined processes had higher treatment efficiency than those of individual processes (23). Yousefi et al investigated the Landfill leachate treatment by modified ABR/AF at different OLRs and HRTs. They reported maximum COD removal efficiency in $10.72 \mathrm{~kg}$ $\mathrm{COD} / \mathrm{m}^{3} / \mathrm{d}$ OLR and 3-day HRT and average removal efficiency varied from $39 \%$ to $96 \%, 39 \%$ to $58 \%$ and $4 \%$ to $16 \%$ for $\mathrm{COD}, \mathrm{BOD}_{5}$ and orthophosphate, respectively (24). Different studies reported the efficiency of AF for a wide range of OLR and HRT (25-30).

In this study, combined ABR and AF was used to treat SWW at a pilot scale. Among different parameters, OLR and HRT are the most important parameters in anaerobic processes that must be optimally controlled. The aim of this study was to investigate the optimum OLR and HRT of two high-rate reactors (ABR and AF) in anaerobic treatment of high-strength SWW.

\section{Materials and Methods}

Slaughterhouse wastewater

Raw wastewater used in this basic and applied study was collected three times in a week from an industrial slaughterhouse in Sari, Iran. The raw wastewater was screened to separate coarse particles larger than $3 \mathrm{~mm}$ and stored in a refrigerator at $4-8^{\circ} \mathrm{C}$ before use. Analysis of the wastewater was carried out several times and the average composition is displayed in Table 1. By changing blood and water ratio, different OLRs and COD concentrations were provided for the reactors.

\section{Experimental set-up}

In this study, a three-pilot-scale system consisted of ABR and an AF was designed and built up in Mazandaran University of Medical Sciences wastewater treatment plant. Schematic representations of the reactors used in the experiments are shown in Figure 1.

\section{Anaerobic baffled reactor}

Three ABR reactors $\left(A_{1}, A_{2}\right.$ and $\left.A_{3}\right)$ with effective volume of 250, 200 and $130 \mathrm{~L}$ were used, respectively. These reactors were right-angle shaped and entirely made up by $\mathrm{PE}$ (Population Equivalent) consisted of 4 equalvolume compartments. Each compartment was further divided into two small chambers by a $45^{\circ}$ slanted-edge baffle leading to downflow and upflow of the wastewater.

Table 1. Characteristics of the slaughterhouse wastewater

\begin{tabular}{lcc}
\hline Parameters & Range & Number of samples \\
\hline $\operatorname{COD}(\mathrm{mg} / \mathrm{L})$ & $2000-10000$ & 23 \\
$\operatorname{TKN}(\mathrm{mg} / \mathrm{L})$ & $42-227$ & 23 \\
$\operatorname{TP}(\mathrm{mg} / \mathrm{L})$ & $23-129$ & 23 \\
$\mathrm{pH}$ & $7.15-7.68$ & 27 \\
Temperature $\left({ }^{\circ} \mathrm{C}\right)$ & $15-30$ & 27 \\
\hline
\end{tabular}




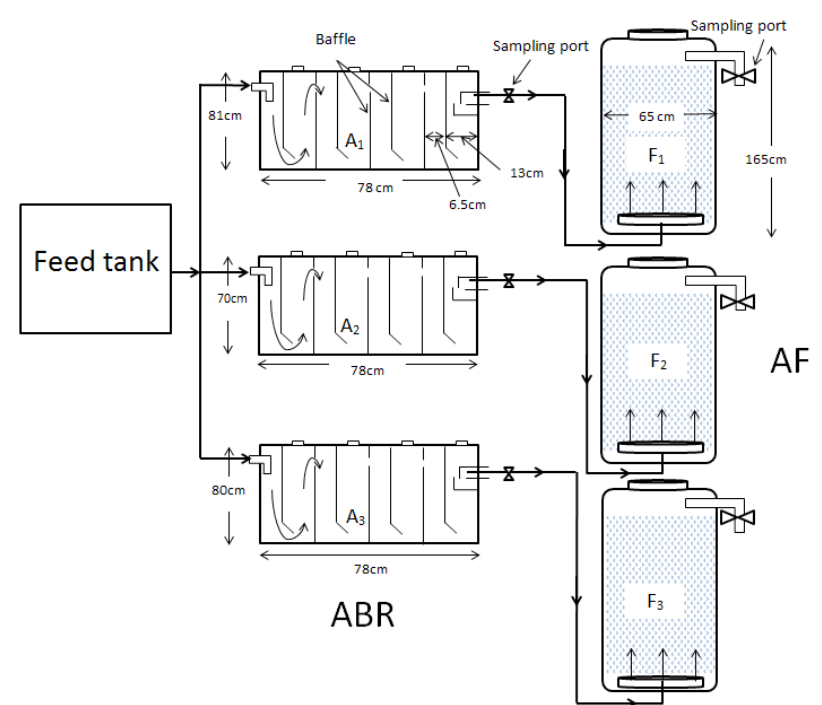

Figure 1. Schematic diagrams of the experimental set-up for the combined processes of $A B R$ and $A F$ reactor.

This structure provided an effective mixing and contact time between the biomass and wastewater within each compartment. The wastewater sampling ports were located at the inlet and outlet zone of each reactor.

\section{Anaerobic filter}

Three identical polyethylene (PE) cylinders $(65 \mathrm{~cm}$ inner diameter, $165 \mathrm{~cm}$ height) with $300 \mathrm{~L}$ effective volume were used as $\operatorname{AF}\left(F_{1}, F_{2}\right.$ and $\left.F_{3}\right)$ in this study. The wastewater entered each reactor from the bottom (under the bed support media) through a T-inlet connected to the ABR reactor outlet. Two-thirds of the reactor $(100 \mathrm{~cm})$ was filled with polyvinyl chloride (PVC) corrugated tubes (3 $\mathrm{cm}$ height and $1.5 \mathrm{~cm}$ in diameter) that were employed as random supporting materials. The reactor packing medium provided a specific surface area of $250 \mathrm{~m}^{2} / \mathrm{m}^{-3}$ and a porosity of $93 \%$ for biomass attachment, thus, the working volume of AF reactors was $280 \mathrm{~L}$. At the outlet of the AF reactor, one sampling port was allowed to take grab samples. All calculations of HRTs and OLRs were based on the reactors effective volumes and the wastewater daily flow rates.

\section{Inoculum}

The inoculum used for reactors start-up was a mixture of 200 L digested sewage sludge obtained from Sari municipal wastewater treatment plant (WWTP) and $80 \mathrm{~L}$ SWW taken from the equalization basin of Mazandaran slaughterhouse WWTP. The mixture was screened to remove coarse materials and then transferred to $\mathrm{ABR}$ reactors (30\% of total volume) and $\mathrm{AF}$ ( $10 \%$ total volume). After three days, 1001 diluted SWW with $1000 \mathrm{mg}$ COD/L were added to ABR and these reactors effluent used as AF reactors influent. During the acclimatization period (153 days), raw wastewater concentration gradually increased up to $4000,3000,2000 \mathrm{mg} C O D / 1$ in $\mathrm{ABR}$ reactors $A_{1}, A_{2}$ and $A_{3}$, respectively. As $A B R$ and $A F$ were fully acclimatized, the combined processes were operated continuously for a total of 152 days at various HRTs (1224 hours) and OLRs under ambient temperature (15.2$35.5^{\circ} \mathrm{C}$ ). In order to obtain a steady-state condition after changing the OLRs and HRTs from one to another, the systems were allowed to run for three HRTs before taking any sample for measurement.

\section{Analytical methods}

The following parameters were analyzed twice a week during the 6-month study period: COD, TKN, TP, total solids (TS) and total suspended solids (TSS) according to standard methods for the examination of water and wastewater (20th edition). The COD was determined by the closed reflux method and direct reading spectrophotometer (DR/2800, HACH, USA). TKN was measured using the macro-Kjeldahl procedure and titrimetric method for ammonia nitrogen determination, TP was measured by the persulfate digestion and stannous chloride method, TSS and TS were measured by the gravimetric method, $\mathrm{pH}$ was determined electrometrically and nitrate was determined by following the procedure described by USEPA (method 352.1).

Data were analyzed using analytical statistics (analysis of variance, ratio, etc) by SPSS and Excel software.

\section{Results}

Effects of HRT and OLR in ABR

The effect of changing HRTs and OLRs on the effluent characteristics was analyzed to determine the relationship between both parameters and optimize condition for systems performance in terms of removal efficiencies, reactors stability etc.

Figure 2 shows the evaluation of COD removal efficiency for three HRTs (12, 18 and 24 hours) and three OLRs (4, 7 and $\left.10 \mathrm{~kg} \mathrm{COD} / \mathrm{m}^{3} / \mathrm{d}\right)$.

Results showed that when OLR increased from 4,7 to $10 \mathrm{~kg} \mathrm{COD} / \mathrm{m}^{3} / \mathrm{d}$, the COD removal efficiency had an increasing trend and reached maximum COD removal

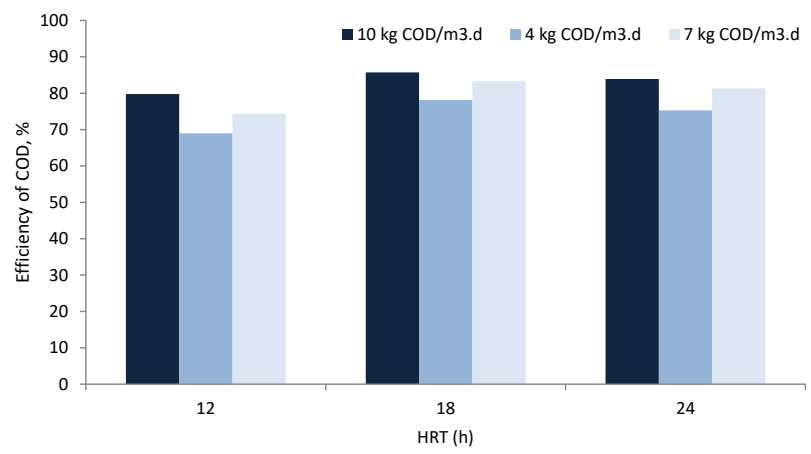

Figure 2. Average COD removal efficiency at different HRTs and OLRs in ABR treating raw SWW. 
efficiency of $83.29 \%$ and $85.72 \%$ at an OLR of 7 and $10 \mathrm{~kg}$ $\mathrm{COD} / \mathrm{m}^{3} / \mathrm{d}$, respectively (Figure 2 ).

According to Table 2, OLR $7 \mathrm{~kg} / \mathrm{m}^{3} / \mathrm{d}$ and HRT $18 \mathrm{~h}$ was the optimum condition for $\mathrm{ABR}$ and the highest removal efficiency and stability were obtained in this condition.

\section{Effects of HRT and OLR in AF performance}

In this section, different OLRs and HRTs were investigated in AF to determine the effects of the process parameters (HRT and OLR) on the reactor performance and stability and also to develop an optimum situation for pollutant removal using a continuous AF reactor. For this reason, three AF reactors $\left(F_{1}, F_{2}\right.$ and $\left.F_{3}\right)$ were used at different HRTs (18, 24 and 36 hours) and OLRs (0.4-1.55 kg COD/ $\left.\mathrm{m}^{3} / \mathrm{d}\right)$. After reactors start-up, the initial HRT was set at 36 hours and then decreased to 24 and 18 hours (first phase), then it was set at 18 and increased to 24 and 36 hours (second phase), and finally, it was set at 36 hours and then decreased to 24 and 18 hours (third phase). Table 3 shows different runs performed and the HRT and OLR tested for each reactor in this study. Removal efficiency at each HRT and OLR under steady-state operations is presented in Figures 3-5. The experimental analyses were intermitted because of the adaptation of the reactor to the OLR changes. In this study, 27 measurements were performed for all reactors.

As shown in Figures 3-5, at HRT 36 hours, the highest removal efficiency was observed in the reactors $\mathrm{F} 1, \mathrm{~F} 2$ and $\mathrm{F} 3$, respectively. The $\mathrm{F}_{1}$ reactor at an OLR of $1 \mathrm{~kg} \mathrm{COD/}$ $\mathrm{m}^{3} / \mathrm{d}$ showed the highest removal efficiency of $68.83 \%$, $78.46 \%$ and $79.39 \%$ at HRT of 18,24 and 36 hours,

Table 2. Summary of COD performance of three ABRs at different OLRs and HRTs in treating SWW

\begin{tabular}{lccc}
\hline Reactor number & OLR $\left(\mathbf{k g ~ C O D} / \mathrm{m}^{3} / \mathrm{d}\right)$ & HRT $(\mathrm{h})$ & Percent removal \\
\hline $\mathrm{A}_{1}$ & 4 & 12 & 68.96 \\
$\mathrm{~A}_{2}$ & 4 & 18 & 78.13 \\
$\mathrm{~A}_{3}$ & 4 & 24 & 75.3 \\
$\mathrm{~A}_{1}$ & 7 & 12 & 74.35 \\
$\mathrm{~A}_{2}$ & 7 & 18 & 83.29 \\
$\mathrm{~A}_{3}$ & 7 & 24 & 81.34 \\
$\mathrm{~A}_{1}$ & 10 & 12 & 79.76 \\
$\mathrm{~A}_{2}$ & 10 & 18 & 85.72 \\
$\mathrm{~A}_{3}$ & 10 & 24 & 83.91 \\
\hline
\end{tabular}

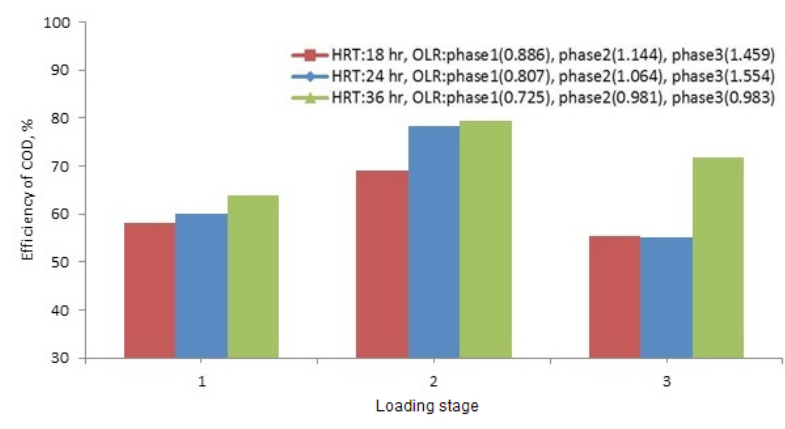

Figure 3. Summary of COD performance of $\mathrm{AF}_{1}$ at different OLRs and HRTs in treating $\mathrm{ABR}_{1}$ effluent.

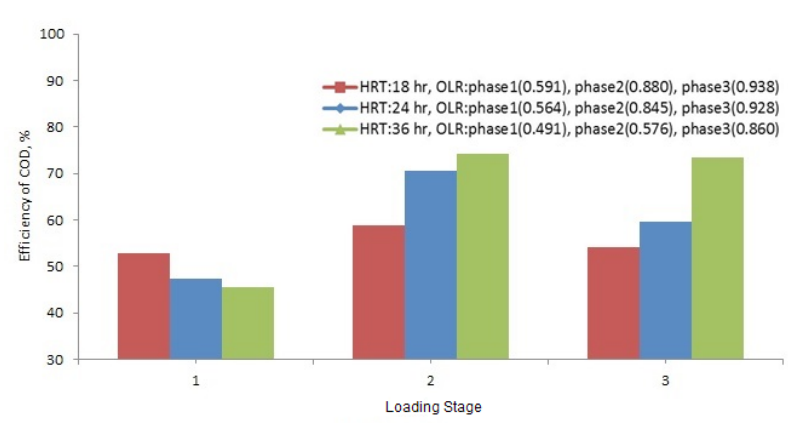

Figure 4. Summary of COD performance of $\mathrm{AF}_{2}$ at different OLRs and HRTs in treating $\mathrm{ABR}_{2}$ effluent.

respectively. $\mathrm{F}_{2}$ showed removal efficiency of $59.2 \%$, $70.97 \%$ and $74.09 \%$ at OLR of $0.760 \mathrm{~kg} \mathrm{COD} / \mathrm{m}^{3} / \mathrm{d}$ and HRT of 18, 24 and 36 hours, respectively. And $\mathrm{F}_{3}$ showed COD removal efficiency of $52.6 \%, 58.5 \%$ and $63.14 \%$ at OLR of $0.764 \mathrm{~kg} \mathrm{COD} / \mathrm{m}^{3} / \mathrm{d}$ and HRT of 18,24 and 36 hours, respectively.

\section{Discussion}

According to previous studies, the increase of OLR and HRT had significant effects on the effluent characteristics, thus, the COD was used as one of the most important parameters to compare the performance of the reactors and monitor the effect of these parameters throughout the study (20-24,29). These studies showed that COD concentrations in the influent (raw wastewater) ranged between 2000 and $10000 \mathrm{mg} / \mathrm{L}$ for ABR and 190 and 970 $\mathrm{mg} / \mathrm{L}$ for AF.

The effects of OLRs were studied in a continuous system by varying the influent COD concentrations; it was revealed

Table 3. Details of operation conditions of AF used in the treatment of SWW in treatment studies

\begin{tabular}{lcccccccccc}
\hline \multirow{2}{*}{ Parameters } & \multicolumn{3}{c}{ Phase 1 } & \multicolumn{3}{c}{ Phase 2 } & \multicolumn{3}{c}{ Phase 3 } \\
\cline { 2 - 12 } & & Run 1 & Run 2 & Run 3 & Run 4 & Run 5 & Run 6 & Run 7 & Run 8 & Run 9 \\
\hline HRT (h) & & 36 & 24 & 18 & 18 & 24 & 36 & 36 & 24 & 18 \\
OLR (kg COD/m $\left.\mathrm{m}^{3} . \mathrm{d}\right)$ & $\mathrm{F}_{1}$ & 0.725 & 0.807 & 0.886 & 1.144 & 1.064 & 0.981 & 0.983 & 1.554 & 1.459 \\
& $\mathrm{~F}_{2}$ & 0.491 & 0.564 & 0.591 & 0.880 & 0.845 & 0.576 & 0.860 & 0.928 & 0.938 \\
& $\mathrm{~F}_{3}$ & 0.417 & 0.584 & 0.574 & 0.906 & 0.826 & 0562 & 0.846 & 0.788 & 0.874 \\
\hline
\end{tabular}




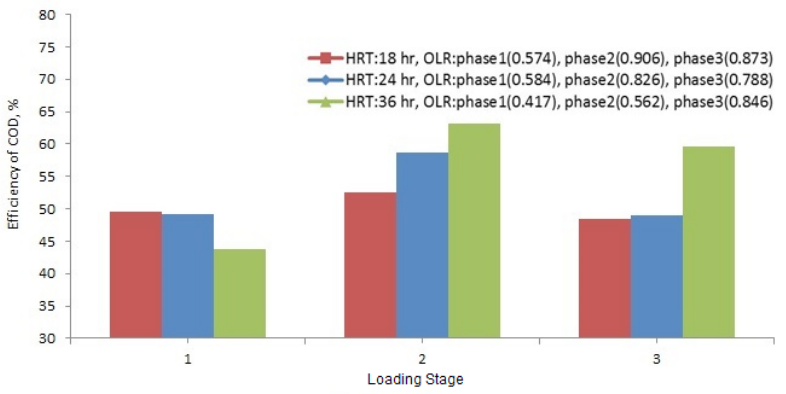

Figure 5. Summary of COD performance of $\mathrm{AF}_{3}$ at different OLRs and HRTs in treating $\mathrm{ABR}_{3}$ effluent

that by increasing the OLR, the effluent COD was also increased and a significant increase in the effluent COD was observed at the highest $\operatorname{OLR}\left(10 \mathrm{~kg} / \mathrm{m}^{3} / \mathrm{d}\right)$ (Figure 2). The results showed that COD removal efficiency was significantly increased with increase of the HRT from 12 to 18 and 24 hours at a constant OLR, however, with increase of the HRT from 18 to 24 hours, a slight increase in the system removal efficiency was observed. The maximum COD removal efficiency in the ABR processes was observed at 18 hours HRT, in this situation, the COD removal efficiencies were $78.13 \%, 83.29 \%$ and $85.72 \%$ at 4,7 and $10 \mathrm{~kg} / \mathrm{m}^{3} / \mathrm{d}$ OLR, respectively, which is consistent with the results of the previous studies $(14,26,29)$. At the lowest HRT (12 hours), the effluent COD removal rate was reduced to $68.96 \%, 74.35 \%$ and $79.76 \%$ at OLR 4,7 and $10 \mathrm{~kg} / \mathrm{m}^{3} / \mathrm{d}$, respectively, which was attributed to the incomplete anaerobic digestion and an onwards slight sludge wash-out.

According to Table 2, at a fixed OLR, the treatment efficiency did not depend on the HRT when it was longer than $18 \mathrm{~h}$. But when a considerably lower HRT (12 hours) and a high OLR $\left(10 \mathrm{~kg} / \mathrm{m}^{3} / \mathrm{d}\right)$ were applied, removal efficiency decreased to $68.96 \%$. However, with higher HRT (18-24 hours), an OLR of $10 \mathrm{~kg} \mathrm{COD} / \mathrm{m}^{3} / \mathrm{d}$ did not show such destabilization, which shows the great influence of high HRT over process stability. Despite an increase in the COD removal efficiencies, by increasing OLR from 7 to 10 $\mathrm{kg}$, the variance explained by this variable was 2.77 and 6.8 in the optimum HRT (18 hours), respectively.

As shown in Figures 3-5, the removal of COD was not significantly declined when the OLR increased except at HRT 24 hours by $23 \%, 11 \%$ and $9 \%$ reduction in $\mathrm{F}_{1}, \mathrm{~F}_{2}$ and $\mathrm{F}_{3}$, respectively. The results indicate that the increase of HRT from 18 to 36 hours significantly improved the COD removal in AF reactor because the longer HRT allowed an effective conversion of the substrate and COD removal was relatively high at all OLRs.

The results of this research are not consistent with some research (21-23). The reason for this discrepancy is that the loading conditions for the published results were not the same and also the researchers have announced the results in lower loading. However, they are consistent with the findings of some studies (24-30), and the higher efficiency for more powerful sewage in this study was obtained, as with other studies $(9,11,15,24)$.

\section{Conclusion}

In summary, the combined $\mathrm{ABR}$ and $\mathrm{AF}$ appears to be a potentially useful reactor for use in SWW treatment. It was concluded that the ABR processes exhibited higher treatment ability in the optimal conditions for the COD reduction. The optimum HRT in ABR was determined as 18 hours; at this situation, the impacts of different OLRs on the removal efficiency were investigated. The optimum OLR was $7 \mathrm{~kg} \mathrm{COD} / \mathrm{m}^{3} / \mathrm{d}$ for the ABR in this study. The results showed that the increase of HRT from 18 to 36 hours significantly improved the COD removal in AF because longer HRT allowed an effective conversion of the substrates and COD removal was relatively high at all OLRs. The optimum HRT was determined as $36 \mathrm{~h}$ and the optimal OLR was $1,0.760$ and $0.764 \mathrm{~kg} \mathrm{COD} / \mathrm{m}^{3} / \mathrm{d}$ in $\mathrm{F}_{1}$, $\mathrm{F}_{2}$ and $\mathrm{F}_{3}$ reactors, respectively.

\section{Acknowledgements}

This study was supported by Sari Public Health School and Vice Chancellor for Research and Technology in Mazandaran University of Medical Sciences. Also, this paper extracted from an MSc thesis and research project that approved by Vice Chancellor for Research and Technology in Mazandaran University of Medical Sciences (code: 952). The authors would like to gratitude Masoumali Movahedi for his sincere cooperation in this research.

\section{Ethical issues}

The authors hereby certify that this manuscript is the original work of the authors, and no data from this work has been or will be published elsewhere separately.

\section{Competing interests}

The authors declare that they have no competing interests.

\section{Authors' contribution}

All authors contributed and participated in the data collection, analysis, and interpretation. All authors reviewed, refined, and approved the manuscript.

\section{References}

1. United States Environmental Protection Agency. EPA821-R-04-011. Technical Development Document for the Final Effluent Limitations Guidelines and Standards for the Meat and Poultry Products Point Source Category (40 CFR 432). Washington, DC: EPA; 2004.

2. Bibbal D, Kerouredan M, Loukiadis E, Scheutz F, Oswald E, Brugere H. Slaughterhouse effluent discharges into rivers not responsible for environmental occurrence of enteroaggregative Escherichia coli. Vet Microbiol 2014; 168(2-4): 451-4. doi: 10.1016/j.vetmic.2013.11.042. 
3. Jensen PD, Sullivan T, Carney C, Batstone DJ. Analysis of the potential to recover energy and nutrient resources from cattle slaughterhouses in Australia by employing anaerobic digestion. Appl Energy 2014; 136: 23-31. doi: 10.1016/j. apenergy.2014.09.009.

4. Rajakumar R, Meenambal T, Banu JR, Yeom IT. Treatment of poultry slaughterhouse wastewater in upflow anaerobic filter under low upflow velocity. Int J Environ Sci Technol 2011; 8(1): 149-58. doi: 10.1007/bf03326204.

5. Keskes S, Hmaied F, Gannoun H, Bouallagui H, Godon JJ, Hamdi M. Performance of a submerged membrane bioreactor for the aerobic treatment of abattoir wastewater. Bioresour Technol 2012; 103(1): 28-34. doi: 10.1016/j. biortech.2011.09.063.

6. Jensen PD, Yap SD, Boyle-Gotla A, Janoschka J, Carney C, Pidou M, et al. Anaerobic membrane bioreactors enable high rate treatment of slaughterhouse wastewater. Biochem Eng J 2015; 97: 132-41. doi: 10.1016/j.bej.2015.02.009.

7. Del Nery V, Damianovic MH, Pozzi E, de Nardi IR, Caldas VEA, Pires EC. Long-term performance and operational strategies of a poultry slaughterhouse waste stabilization pond system in a tropical climate. Resources Conservation and Recycling 2013; 71: 7-14. doi: 10.1016/j. resconrec.2012.11.006.

8. Budiyono, Widiasa IN, Johari S, Sunarso. Study on slaughterhouse wastes potency and characteristic for biogas production. Int J Waste Resour 2011; 1(2): 4-7. doi: 10.4172/2252-5211.1000102.

9. Bazrafshan E, Kord Mostafapour F, Farzadkia M, Ownagh KA, Mahvi AH. Slaughterhouse wastewater treatment by combined chemical coagulation and electrocoagulation process. PLoS One 2012; 7(6): e40108. doi: 10.1371/journal. pone.0040108.

10. Bayar S, Yildiz Y, Yilmaz A, Koparal AS. The effect of initial $\mathrm{pH}$ on treatment of poultry slaughterhouse wastewater by electrocoagulation method. Desalination Water Treat 2014; 52(16-18): 3047-53. doi: 10.1080/19443994.2013.800268.

11. Sunder GC, Satyanarayan S. Efficient treatment of slaughter house wastewater by anaerobic hybrid reactor packed with special floating media. International Journal of Chemical and Physical Sciences 2013; 2: 73-81.

12. Hossaini H, Fatehizadeh A, Yousefi N, Reshadat S, Rajabi Gilan N, Ghasemi SR, et al. Application of enhanced softening process in slaughterhouse wastewater treatment. Indian J Chem Technol 2013; 20(3): 217-21.

13. Johns MR. Developments in wastewater treatment in the meat processing industry: a review. Bioresour Technol 1995; 54(3): 203-16. doi: 10.1016/0960-8524(95)00140-9.

14. Mittal GS. Treatment of wastewater from abattoirs before land application--a review. Bioresour Technol 2006; 97(9): 1119-35. doi: 10.1016/j.biortech.2004.11.021.

15. Nguyen H, Turgeon S, Matte J. The Anaerobic Baffled Reactor: A study of the wastewater treatment process using the anaerobic baffled reactor. Massachusetts: Worcester Polytechnic Institute; 2010.

16. Shakeri M, Vossoughi M. Coupled anaerobic baffled reactor
(ABR)/activated sludge treatment of synthetic wastewater with high concentration of sulfate and COD. International Journal of Engineering 2003; 16(1): 11-20.

17. Foxon KM, Pillay S, Lalbahadur T, Rodda N, Holder F, Buckley CA. The anaerobic baffled reactor (ABR): an appropriate technology for on-site sanitation. Water SA 2004; 30(5): 44-50. doi: 10.4314/wsa.v30i5.5165.

18. Boopathy R, Tilche A. Anaerobic digestion of high strength molasses wastewater using hybrid anaerobic baffled reactor. Water Res 1991; 25(7): 785-90. doi: 10.1016/00431354(91)90157-L.

19. Barber WP, Stuckey DC. The use of the anaerobic baffled reactor (ABR) for wastewater treatment: a review. Water Res 1999; 33(7): 1559-78. doi: 10.1016/S0043-1354(98)00371-6.

20. Liu RR, Tian Q, Yang B, Chen JH. Hybrid anaerobic baffled reactor for treatment of desizing wastewater. Int J Environ Sci Technol 2010; 7(1): 111-8. doi: 10.1007/bf03326122.

21. Gopala Krishna GV, Kumar P, Kumar P. Treatment of low strength complex wastewater using an anaerobic baffled reactor (ABR). Bioresour Technol 2008; 99(17): 8193-200. doi: 10.1016/j.biortech.2008.03.016.

22. Bodkhe SY. A modified anaerobic baffled reactor for municipal wastewater treatment. J Environ Manage 2009; 90(8): 2488-93. doi: 10.1016/j.jenvman.2009.01.007.

23. Cao W, Mehrvar M. Slaughterhouse wastewater treatment by combined anaerobic baffled reactor and UV/H2O2 processes. Chem Eng Res Des 2011; 89(7): 1136-43. doi: 10.1016/j.cherd.2010.12.001.

24. Yousefi Z, Yazdani Cherati J, Movahedi M, Kariminejad F. Effect of Organic Loading Rate on the Performance of Anaerobic Process in Treatment of Pulp and Paper Mill Effluents. Journal of Mazandaran University of Medical Sciences 2015; 25(131): 136-50. [In Persian]

25. Rajakumar R, Meenambal T. Comparative Study on startup performance of HUASB and AF reactors treating poultry slaughterhouse wastewater. Int J Environ Res 2008; 2(4): 401-10. doi: 10.22059/ijer.2010.221.

26. Tritt WP. The anaerobic treatment of slaughterhouse wastewater in fixed-bed reactors. Bioresour Technol 1992; 41(3): 201-7. doi: 10.1016/0960-8524(92)90002-F.

27. Omil F, Garrido JM, Arrojo B, Mendez R. Anaerobic filter reactor performance for the treatment of complex dairy wastewater at industrial scale. Water Res 2003; 37(17): 4099-108. doi: 10.1016/s0043-1354(03)00346-4.

28. del Pozo R, Diez V, Beltrán S. Anaerobic pre-treatment of slaughterhouse wastewater using fixed-film reactors. Bioresour Technol 2000; 71(2): 143-9. doi: 10.1016/S09608524(99)90065-2.

29. Kobayashi HA, Stenstrom MK, Mah RA. Treatment of low strength domestic wastewater using the anaerobic filter. Water Res 1983; 17(8): 903-9. doi: 10.1016/00431354(83)90164-1.

30. Bodik I, Herdova B, Drtil M. The use of upflow anaerobic filter and AnSBR for wastewater treatment at ambient temperature. Water Res 2002; 36(4): 1084-8. doi: 10.1016/ s0043-1354(01)00308-6. 